\title{
ISOLATION OF SHIGA TOXIN-PRODUCING ESCHERICHIA COLI (STEC) SEROTYPE O91:H21 FROM A CHILD WITH DIARRHEA IN PORTO ALEGRE CITY, RS, BRAZIL
}

\author{
Vlademir Cantarelli ${ }^{1,2 *}$; Kenichi Nagayama ${ }^{1}$; Akira Takahashi' ${ }^{1}$; Takeshi Honda ${ }^{1}$; Paulo F. \\ Cauduro $^{2}$; Cícero A.G. Dias²; Adelina Mezzari²; Teresa Brodt ${ }^{2}$ \\ ${ }^{1}$ Department of Bacterial Infections, Research Institute for Microbial Diseases, Osaka University, Osaka, Japan. \\ ${ }^{2}$ Laboratório Weinmann Ltda., Porto Alegre, RS, Brasil
}

Submitted: July 27, 1999; Returned to authors for corrections: January 13, 2000; October 06, 2000

\section{SHORT COMMUNICATION}

\begin{abstract}
We describe the isolation of one strain of Shiga toxin-producing Escherichia coli O91:H21 from a child with diarrhea in the city of Porto Alegre, RS, Brazil. Considering the pathogenic potential of STEC, these organisms should be looked for more carefully among our population.
\end{abstract}

Key words: enterohemorrhagic E. coli, STEC, enteroaggregative E. coli, enteropathogenic E. coli, diarrhea

Enterophatogenic Escherichia coli (EPEC) was the first category of $E$. coli to be implicated in gastrointestinal diseases (1). In the 70's two other categories of diarrheagenic E. coli were described: enterotoxigenic E. coli (ETEC) and enteroinvasive E. coli (EIEC) (19). During the 80's, the demonstration that EPEC strains could adhere to epithelial cells in culture (4) resulted in the description of two new categories of E. coli: enteroaggregative E. coli (EAEC or EAggEC) and diffuse adhering $E$. coli (DAEC) $(20,24)$. The diarrheagenic potential of EAEC and DAEC was a matter of controversies, however, both categories were recently reported to cause diarrheal diseases, and EAEC is now considered an emerging pathogen (19). EAEC was significantly associated with persistent diarrhea ( $\geq 14$ days) and growth retardation in the Northeast of Brazil (27). In another report, EAEC was isolated only from patients in similar frequency for acute and persistent diarrhea (23). EAEC may also represent a potential cause of diarrhea among AIDS patients (31).

Shiga toxin-producing E. coli (STEC) is another category of organisms with the potential to cause diarrheal disease. The major virulence factor produced by these organisms is Shiga toxin (Stx 1 and Stx2, also called verocytotoxins), which seems to be directly responsible for the hemorrhagic colitis (HC) or hemolytic-uremic syndrome (HUS) developed by some patients following STEC infection. HUS may result in permanent renal failure, and sometimes leads the patient to death (13). Subsets of STEC that are able to cause attaching and effacing (A/E) lesions similar to EPEC organisms are termed enterohemorrhagic E. coli (EHEC, or typical EHEC) (19). Even though EHEC serotype $\mathrm{O} 157: \mathrm{H} 7$ is the organisms most often implicated in large outbreaks, others serotypes have been reported to cause a considerable number of cases of HUS in many countries, specially in the southern hemisphere (Reviewed in ref. 11). STEC from various serotypes, including serotype O157:H7, were isolated in high frequency from cattle in Rio de Janeiro State, Brazil (3). A previous epidemiological study conducted in Rio de Janeiro, however, detected no STEC organisms from urban children less than 2 years old (22).

Both EHEC and EPEC possess a large chromosomal region called LEE (locus of enterocyte effacement) (9). This region contains genes involved in adherence, such as eae (for intimin) and tir (for translocated intimin receptor), as well as genes involved in the production and delivery of virulence factors into the infected intestinal cells (For details see ref. 5, and 10). STEC strains that do not posses eae gene have been isolated from patients in sporadic cases of HC and HUS, as well as

\footnotetext{
* Corresponding author. Mailing Address: Laboratório Weinmann, R. Ramiro Barcelos, 910, $5^{\circ}$ and., CEP 94035-001, Porto Alegre, RS, Brasil.
} 
outbreaks (6). STEC strains isolated from HUS patients that produce Stx 2 and adhere to cells in culture in an aggregative pattern have also been described $(6,17)$. These strains were negative for the presence of $e a e$ gene and may possess distinct adherence factors (17).

The use of serology alone to differentiate enteropathogenic strains of $E$. coli may be misleading, since within a certain "O" serogroup different categories of $E$. coli may be present (29). Recently, molecular methods such as "Polymerase Chain Reaction" (PCR) and molecular probes have been extensively used to detect $E$. coli involved in gastrointestinal infections (19).

In this report we further characterized a group of sixteen $E$. coli that agglutinated with anti-EPEC polyvalent antiserum during screening for EPEC serogroups. The $E$. coli strains were isolates from patient's fecal samples submitted to our laboratory during the period from November 1995 to June 1996. During this period, a total of 1756 fecal cultures were processed, among them 375 were from children less than 2 years old and were screened for the presence of possible EPEC organisms in the absence of another enteropathogen, such as Salmonella sp., Shigella sp. or Campylobacter sp.

Three to six lactose-fermenting and two to three lactosenegative colonies from a MacConkey agar plate were biochemically confirmed to be E. coli, and then screened using anti-EPEC polyvalent antisera (Probac, Brazil) as directed by the manufacturer. The polyvalent antisera consist of three separated pools, being able to react with the following serogroups: O26, O55, O86, O111, O114, O119, O125, O126, O127, $\mathrm{O} 128, \mathrm{O} 142$, and O158. Sixteen strains from different patients, named $\mathrm{Br} 1$ to $\mathrm{Br} 16$, agglutinated with the EPEC polyvalent antiserum and were further tested with monovalent antisera (Denka Seiken, Japan), following exactly the manufacturer's instructions. Serotyping of strain $\mathrm{Br} 12$ was kindly performed by Dr. Teizo Tsukamoto at the Osaka Prefectural Institute of Public Health, Osaka, Japan.

Control strains were used in all the experiments. For positive controls, the following strains from the Research Institute for Microbial Diseases (RIMD) bacterial culture collection were used: RIMD 0509829, a typical EPEC strain belonging to serotype O111:H2, and RIMD 0509952, an EHEC strain serotype O157:H7 isolated in Osaka, Japan, that secretes Shiga toxins (Stx1 and Stx2); and the ETEC strain RIMD0509266 that produces both heat-labile (LT) and heat-stable toxins (ST1). Non-pathogenic E. coli strain HB101 was used as a negative control. Adhesion assay and the Fluorescent Actin Staining (FAS) assay were performed using HeLa cells (Riken, Japan), essentially as described by Cravioto et al. and Knutton et al. $(4,15)$, respectively. For both tests, the infected cells were washed three times with phosphate buffered saline (PBS) $3 \mathrm{~h}$ post infection, then fresh tissue culture medium was added (Dulbecco's Modified Eagle's Media, DMEM, Sigma Chemical
Co., St. Louis, Mo.) and the infection was allowed to proceed for a total of $6 \mathrm{~h}$. The FAS assay was performed using fluorescent rhodamine-labeled phalloidin (Molecular Probes Inc., Eugene, Ore., USA) to stain the infected cell monolayers. Primers EAE1 (5'-CCC GGC ACA AGC ATA AGC TAA-3') and EAE2 (5'-ATG ACT CAT GCC AGC CGC TCA-3') were used to amplify a 920 bp segment of the eae gene of both EPEC and STEC (this study). The following PCR primers were also used in this study. pCVD432/start (5'-CTG GCG AAA GAC TGT ATC AT-3') and pCVD432/stop (5'-CAA TGT ATA GAA ATC CGC TGT T-3') to detect EAEC (25); for ETEC heat-labile toxin (LT), the upstream primer TW20 (5'-GGC GAC AGA TTA TAC CGT GC-3') and the downstream primer JW11 (5'-CGG TCT CTA TAT TCC CTG TT-3') were used (26); for ETEC heat-stable toxin (STI), the degenerated upstream primer JW14 (5'-ATT TTT MTT TCT GTA TTR TCT T-3'; $\mathrm{M}=\mathrm{A}$ or $\mathrm{C}$ and $\mathrm{R}=\mathrm{A}$ or $\mathrm{G}$ ) and the downstream primer JW7 (5'-CAC CCG GTA CAR GCA GGA TT-3') were used to amplify both the STh and STp gene sequences (26). Stx 1 and Stx 2 genes were simultaneously detected with a single primer pair: MK1 (5'-TTT ACG ATA GAC TTC AC-3') and MK2 (5'-CAC ATA TAA ATT ATT TCG CTC-3') (12), and positive samples were confirmed using primers specific for Stx 1 , SLTI-5 (5'-AGC TGA AGC TTT ACG TTT TCG G-3') and SLTI-3 (5'-TTT GCGCAC TGA GAA GAA GAG A-3'), and St $x 2$ genes, SLTII-5 (5'-TTT CCA TGA CAA CGG ACA GCA GTT-3') and SLTII-3 (5'-ATC CTC ATT ATA CTT GGA AAA CTC A-3') (30). Bacterial DNA from samples and controls was prepared from $200 \mu \mathrm{l}$ of an overnight culture in Luria broth (LB), centrifuged and resuspended in $500 \mu \mathrm{l}$ of deionized water and boiled for $5 \mathrm{~min}$, then kept in a deep freezer until use. Amplification of each gene target was carried out in separate tubes using the Ex Taq polymerase kit (Takara Shuzo Co. Japan) following the instructions provided by the manufacturer. Reaction mixtures contained $5 \mu \mathrm{l}$ of the bacterial DNA in a final volume of $25 \mu \mathrm{l}$. For eae, the reaction mixtures were heated to $95^{\circ} \mathrm{C}$ for $5 \mathrm{~min}$ and were then subjected to 30 cycles of $95^{\circ} \mathrm{C}$ for $45 \mathrm{~s}, 55^{\circ} \mathrm{C}$ for $45 \mathrm{~s}$, and $72^{\circ} \mathrm{C}$ for $45 \mathrm{~s}$, with a final extension performed at $72^{\circ} \mathrm{C}$ for $5 \mathrm{~min}$. Cycling conditions for the others PCR reactions were the same as described in the references cited for each primer set. PCR products were examined by agarose gel electrophoresis comparing samples and controls.

A summary with the characteristics of the 16 strains is shown in Table 1. Strain $\mathrm{Br} 4$ displayed a typical localized adherence (LA) (Fig. 1A), and was also able to induce actin accumulation beneath the bacterial adherence site, as demonstrated by the positive FAS assay. This strain belonged to serogroup O142, and was confirmed by PCR to possess the eae gene. Three strains belonging to serogroup O111, one strain from serogroup O91, and seven strains from non-identified serogroups were classified as EAEC by the typical stacked-bricks adherence pattern to cultured HeLa cells (Fig 1C). PCR for EAEC was positive for only two of the eleven strains initially classified as 
Table 1. Characteristic of Escherichia coli strains analyzed in this study.

\begin{tabular}{|c|c|c|c|c|c|c|c|}
\hline \multirow[t]{2}{*}{ Strain } & \multirow[t]{2}{*}{ Serogroup or Serotype } & \multirow[t]{2}{*}{ Cell Adherence } & \multirow[t]{2}{*}{ FAS assay } & \multicolumn{3}{|c|}{ PCR for: } & \multirow[b]{2}{*}{ ST1/LT } \\
\hline & & & & EAE & EAEC & Stx & \\
\hline $\mathrm{Br} 1$ & ND & AA & - & - & - & - & - \\
\hline $\mathrm{Br} 2$ & ND & AA & - & - & - & - & - \\
\hline $\mathrm{Br} 3$ & ND & AA & - & - & - & - & - \\
\hline $\mathrm{Br} 4$ & $\mathrm{O} 142$ & LA & POS & POS & - & - & - \\
\hline $\mathrm{Br} 5$ & $\mathrm{ND}$ & AA & - & - & - & - & - \\
\hline $\mathrm{Br} 6$ & 0111 & AA & - & - & - & - & - \\
\hline $\mathrm{Br} 7$ & $\mathrm{ND}$ & AA & - & - & - & - & - \\
\hline $\mathrm{Br} 8$ & O111 & AA & - & - & POS & - & - \\
\hline $\mathrm{Br} 9$ & $\mathrm{ND}$ & AA & - & - & - & - & - \\
\hline $\operatorname{Br} 10$ & ND & NA & - & - & - & - & - \\
\hline Br11 & ND & NA & - & - & - & - & - \\
\hline Br12 & O91:H21 & AA & - & - & - & Stx2 & - \\
\hline Br13 & ND & NA & - & - & - & - & - \\
\hline Br14 & O111 & AA & - & - & POS & - & - \\
\hline Br15 & $\mathrm{ND}$ & DA & - & - & - & - & - \\
\hline Br16 & ND & AA & - & - & - & - & - \\
\hline
\end{tabular}

ND, No agglutination with monovalent antiserum against classical EPEC serogroups; AA, aggregative adherence; LA, localized adherence; DA, diffuse adherence; NA, No significant adherence; POS, positive reaction; See text for details.
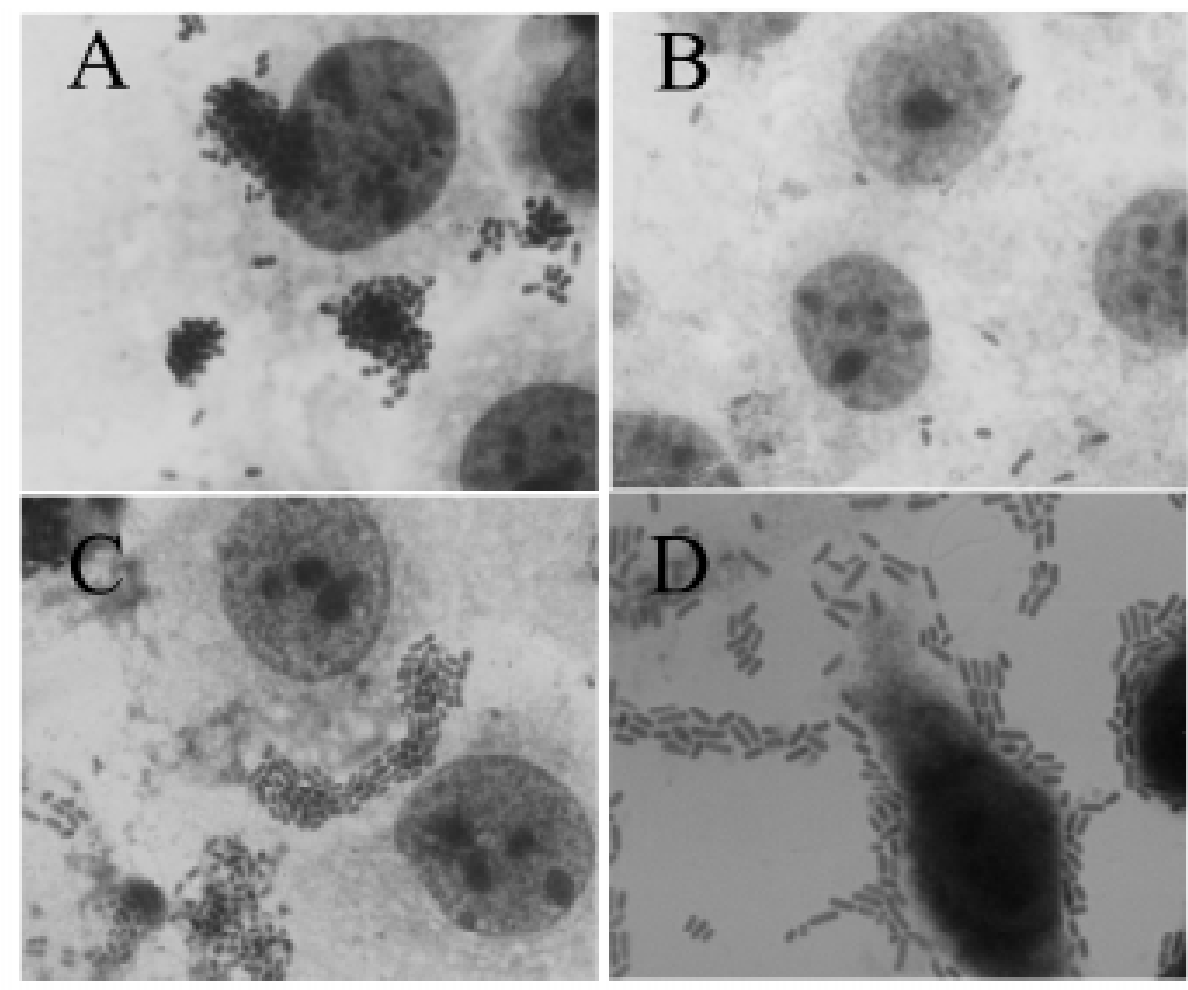

Figure 1. Adherence pattern of Escherichia coli strains isolated in Porto Alegre, RS, Brazil to HeLa cells. Localized adherence (LA) of EPEC strain Br4 (A), aggregative adherence (AA) of EAEC strain Br8 (C), and aggregative adherence of STEC strain Br12 (D). A non-adherent strain $(\mathrm{Br} 10)$ is also shown $(\mathrm{B})$. 
EAEC by the typical cell adherence pattern. This fact was not unexpected, since it was reported that some EAEC strains do not harbor the gene sequence recognized by this primer set (25).

PCR was also performed for all sixteen strains to detect the genes for production of STl and LT by ETEC, and Stx 1 and Stx 2 by STEC. None of the sixteen strains produced ST1 or LT (Table 1). Strain Br12 was positive for $s t x 2$, and the secretion of Stx 2 was confirmed by cytotoxicity to Vero and HeLa cells, and by reverse passive latex agglutination test (Verotox-F, Denka Seiken, Japan) (data not shown). This STEC strain was classified as serotype $\mathrm{O} 91: \mathrm{H} 21$, and confirmed to be negative for eae and the FAS test (Table 1). This strain was able to adhere to HeLa cells in culture displaying an aggregative pattern of attachment (Fig.1D).

To the best of our knowledge, this is the first description of an STEC strain isolated from a patient in the south of Brazil (Porto Alegre, RS). The patient, a two years old child, suffered from diarrhea and no other pathogen could be implicated as the cause of the gastrointestinal disease. The disease did not progressed to HC or HUS. STEC strain belonging to serotype O91:H21 was reported to be isolated from a patient with HUS (7), and from a patient with bloody diarrhea (14). The reason why strain B12 agglutinated with polyvalent antisera is not known, since serogroup O91 is not included among the serogroups recognized by the polyvalent anti-EPEC antiserum employed for initial screening of possible EPEC organisms. A total of eleven other strains of unknown serogroups were also positive with the polyvalent antisera used. It is known, however, that strains tested positive by polyvalent antisera should be confirmed using monovalent antisera, since false positive reactions do occur (2).

Even though eae-positive EHEC strains are more often involved in outbreaks, several cases of HUS have been attributed to eae-negative STEC strains $(21,28)$. It is possible that the concentration of efforts directed to isolate strains of EHEC serotype O157:H7 may cause other STEC strains to be overlooked. Considering that two countries that border with the south of Brazil, Argentina and Uruguay, reported several cases of HUS due to non-O157 strains (16), it should be advisable to look for STEC organisms in stool samples submitted for culture, particularly in those Brazilian States where consumption of beef is high. Contrary to the typical EHEC strains, like O157:H7, the majority of STEC strains do ferment sorbitol, so detection of these organisms is best accomplished by molecular methods, such as PCR, designed to reveal the presence of stx genes.

In conclusion, our pilot study suggests that true EPEC strains may be uncommon among the patients cared for in our laboratory. EAEC organisms appear to be much more prevalent among our patients. The reason why we found a very low prevalence of true EPEC $(0.2 \%)$ is possibly related to the higher socio-economic level of the population attended by our institution. EPEC infection is a common cause of diarrhea in low-income populations $(8,22)$, but its relative importance decreases dramatically when this pathogen is searched for in populations of better socio-economic levels, such as in developed parts of the world $(18,19)$. Since our study was restricted to a group of $16 \mathrm{E}$. coli that initially agglutinated with anti-EPEC polyvalent antisera, the true prevalence of EAEC or STEC among our population is probably underestimated. Finally, considering the life-threatening potential of STEC, the real incidence of these organisms among Brazilian population deserves further studies. We are currently planning a more detailed study to evaluate the prevalence of STEC and other diarrheagenic E. coli among our population in the south of Brazil.

\section{ACKNOWLEDGMENTS}

This study was supported by a grant-in-aid from the Research for the Future program of the Japan Society for the Promotion of Science (JSPS-RFJF 97L00704). V. V. C. thanks Laboratório Weinmann for partial support during the stay in Japan. We thank Dr. Teizo Tsukamoto at the Osaka Prefectural Institute of Public Health for performing the serotyping of strain Br12.

\section{RESUMO}

\section{Isolamento de Escherichia coli 091:H21 produtora de toxina Shiga (STEC) de uma criança com diarréia em Porto Alegre, RS, Brasil}

É descrito o isolamento de uma cepa de Escherichia coli O91:H21 produtora de toxina Shiga (STEC) em associação com diarréia em uma criança da cidade de Porto Alegre, RS, Brasil. Dado o potencial para causar complicações graves, infecções por STECs deveriam ser melhor avaliadas em nossa população.

Palavras-chave: Escherichia coli enterohemorrágica, STEC, Escherichia coli enteroagregativa, Escherichia coli enteropatogênica, diarréia

\section{REFERENCES}

1. Bray, J. Isolation of antigenically homogeneous strains of Bact. coli neapolitanum from summer diarrhoea of infants. J. Pathol. Bacteriol. 57:239-245, 1945.

2. Campos, L. C. Conventional methods for the diagnosis of enteropathogenic Escherichia coli infections. Rev. Microbiol. 27 (Suppl. 1): 50-53, 1996.

3. Cerqueira, A. M. F.; Guth, B. E. C.; Joaquim, R. M.; Andrade, J. R. C. High occurrence of Shiga toxin-producing Escherichia coli (STEC) in healthy cattle in Rio de Janeiro State, Brazil. Vet. Microbiol. 70:111121, 1999. 
4. Cravioto, A.; Gross, R. J.; Scotland, S. M.; Rowe, B. An adhesive factor found in strains of Escherichia coli belonging to the traditional infantile enterophatogenic serotypes. Curr. Microbiol. 3:95-99, 1979.

5. Donnenberg, M. S.; Kaper, J. B.; Finlay, B. B. Interaction between enteropathogenic Escherichia coli and host epithelial cells. Trends Microbiol. 5:109-114, 1997.

6. Dytoc, M. T.; Ismaili, A.; Philpott, D. J.; Soni, R.; Brunton, J. L.; Sherman, P. M. Distinct binding properties of eaeA-negative verocytotoxin-producing Escherichia coli of serotype O113:H21. Infect. Immun. 62:3494-3505, 1994.

7. Furutani, M.; Ito, K.; Oku, Y.; Takeda, Y.; Igarashi, K. Demonstration of RNA N-glycosidase activity of a Vero toxin (VT2 variant) produced by Escherichia coli $091: \mathrm{H} 21$ from a patient with the hemolytic uremic syndrome. Microbiol. Immunol. 34:387-92, 1990.

8. Gomes, T. A. T; Rassi, V.; MacDonald, K. L.; Ramos, S. R. T. S.; Trabulsi, L. R.; Vieira, M. A. M.; Guth, B. E. C.; Candeias, J. A. N.; Ivey, C.; Toledo, M. R. F.; Blake, P. A. Enteropathogens associated with acute diarrheal disease in urban infants in Sao Paulo, Brazil. J. Infect. Dis. 164:331-7, 1991.

9. Jarvis, K. G.; Giron, J. A.; Jerse, A. E.; MacDaniel, T. K.; Donnenberg, M. S.; Kaper J. B. Enteropathogenic Escherichia coli contains a putative type III secretion system necessary for the export of proteins involved in attaching and effacing lesion formation. Proc. Natl. Acad. Sci. USA. 92:7996-8000, 1995.

10. Kaper, J. B. EPEC delivers the goods. Trends Microbiol. 6:169-172, 1998.

11. Kaper, J. B.; O’Brien, A. D. Escherichia coli 0157:H7 and other Shiga toxin-producing E. coli strains. ASM, Washington, 1998, 465p.

12. Karch, H.; Meyer, T. Single primer pair for amplifying segments of distinct Shiga-like-toxin genes by polymerase chain reaction. J. Clin. Microbiol. 27:2751-2757, 1989.

13. Karmali, M. A. Infection by verocytotoxin-producing Escherichia coli. Clin. Microbiol. Rev. 2:15-38, 1989.

14. Keskimaki, M.; Saari, M.; Heiskanen, T.; Siitonen, A. 1998. Shiga toxin-producing Escherichia coli in Finland from 1990 through 1997: prevalence and characteristics of isolates. J. Clin. Microbiol. 36:36413646, 1998.

15. Knutton, S.; Phillips, A. D.; Smith, H. R.; Gross, R. J.; Shaw, R.; Watson, P.; Price, E. Screening for enteropathogenic Escherichia coli in infants with diarrhea by the fluorescent-actin staining test. Infect. Immun. 59(1):365-371, 1991.

16. López, E. L.; Contrini, M. M.; De Rosa, M. F. Epidemiology of Shiga toxin-producing Escherichia coli in South America. In: Kaper, J. B.; O'Brien, A. D. (ed.). Escherichia coli O157:H7 and other Shiga toxinproducing E. coli strains. ASM, Washington, 1998, 465p.

17. Morabito, S.; Karch, H.; Mariani-Kurkdjian, P.; Schmidt, H.; Minelli, F.; Bingen, E.; Caprioli, A. Enteroaggregative, Shiga toxin-producing Escherichia coli O111:H2 associated with an outbreak of hemolyticuremic syndrome. J. Clin. Microbiol. 36:840-842, 1998.

18. Morris, K. J.; Rao, G. G. Conventional screening for enteropathogenic Escherichia coli in the UK. Is it appropriate or necessary? J. Hosp. Infect. 21:163-167, 1992.
19. Nataro, J. P.; Kaper, J. B. 1998. Diarrheagenic Escherichia coli. Clin. Microbiol. Rev. 11:142-201, 1998.

20. Nataro, J. P.; Scaletsky, I. C. A.; Kaper, J. B.; Levine, M. M.; Trabulsi, L. R. Plasmid-mediated factors conferring diffuse and localized adherence of enteropathogenic Escherichia coli. Infect. Immun. 48:378-383, 1985.

21. Ojeda, A.; Prado, V.; Martinez, J.; Arellano, C.; Borczyk, A.; Johnson, W.; Lior, H.; Levine, M. M. Sorbitol-negative phenotype among enterohemorrhagic Escherichia coli strains of different serotypes and from different sources. J. Clin. Microbiol. 33:2199-2201, 1995.

22. Rosa, A. C.; Mariano, A. T.; Pereira, A. M.; Tibana, A.; Gomes, T. A. T.; Andrade, J. R. C. Enteropathogenicity markers in Escherichia coli isolated from infants with acute diarrhoea and healthy controls in Rio de Janeiro, Brazil. J. Med. Microbiol. 47:781-790, 1998.

23. Scaletsky, I. C. A.; Pedroso, M. Z.; Morais, M. B.; Carvalho, R. L.; Silva, R. M.; Fabbricotti, S. H.; Fagundes-Neto, U. Association of patterns of Escherichia coli adherence to HEp-2 cells with acute and persistent diarrhea. Arq. Gastroenterol. 36:54-60, 1999.

24. Scaletsky, I. C. A.; Silva, M. L. M.; Trabulsi, L. R. Distinctive patterns of adherence of enteropathogenic Escherichia coli to HeLa cells. Infect. Immun. 45:534-536, 1984.

25. Schmidt, H.; Knop, C.; Franke, S.; Aleksic, S.; Heesemann, J.; Karch, H. 1995. Development of PCR for screening of enteroaggregative Escherichia coli. J. Clin. Microbiol. 33:701-705, 1995.

26. Stacy-Phipps, S.; Mecca, J. J.; Weiss, J. B. Multiplex PCR assay and simple preparation method for stool specimens detect enterotoxigenic Escherichia coli DNA during course of infection. J. Clin. Microbiol. 33:1054-1059, 1995.

27. Steiner, T. S.; Lima, A. A.; Nataro, J. P.; Guerrant, R. L. Enteroaggregative Escherichia coli produce intestinal inflammation and growth impairment and cause interleukin-8 release from intestinal epithelial cells. J. Infect. Dis. 177:88-96, 1998.

28. Tamura, K.; Sakazaki, R.; Murase, M.; Kosako, Y. Serotyping and categorisation of Escherichia coli strains isolated between 1958 and 1992 from diarrhoeal diseases in Asia. J. Med. Microbiol. 45:353358, 1996.

29. Trabulsi, L. R.; Campos, L. C.; Whittam, T. S.; Gomes, T. A. T. Rodrigues, J.; Gonçalves, A. G. Traditional and non-traditional enteropathogenic Escherichia coli serogroups. Rev. Microbiol. (suppl. 1). 27:1-6, 1996.

30. Tsen, H. Y.; Jian, L. Z. Development and use of a multiplex PCR system for the rapid screening of heat labile toxin I, heat stable toxin II and Shiga-like toxin I and II genes of Escherichia coli in water. $J$. Appl. Microbiol. 84:585-592, 1998.

31. Wanke, C. A.; Mayer, H.; Weber, R.; Zbinden, R.; Watson, D. A.; Acheson, D. Enteroaggregative Escherichia coli as a potential cause of diarrheal disease in adults infected with human immunodeficiency virus. J. Infect. Dis. 178:185-190, 1998. 